\title{
KINERJA BIOSAND FILTER BERBAHAN DASAR BATUAN ANDESIT DALAM MENURUNKAN KONSENTRASI BOD DAN COD PADA AIR TANAH DANGKAL
}

\author{
Tivany Edwin ${ }^{1}$, Yommi Dewilda ${ }^{2}$ dan Aldilla Afiani Alda ${ }^{1}$ \\ ${ }^{1}$ Laboratorium Mikrobiologi Lingkungan Jurusan Teknik Lingkungan Universitas Andalas \\ ${ }^{2}$ Laboratorium Buangan Padat Jurusan Teknik Lingkungan Universitas Andalas \\ Email: tivani@ft.unand.ac.id
}

\begin{abstract}
ABSTRAK
Air tanah dangkal merupakan opsi sumber air bersih yang umum digunakan masyarakat. Tingginya kadar Biochemical Oxygen Demand (BOD) dan Chemical Oxygen demand (COD) terkadang ditemukan pada air tanah dangkal yang menandakan tercemarnya air tersebut. Oleh karena itu diperlukan teknologi tepat guna pengolahan air yang relatif murah dan efisien untuk skala rumah tangga masyarakat seperti biosand filter. Penelitian bertujuan untuk menganalisis kinerja biosand filter dalam menurunkan parameter BOD dan COD pada sampel air tanah dangkal dari sumur penduduk. Biosand filter didesain dengan dimensi reaktor $30 \times 30 \times 90 \mathrm{~cm}$ dengan perbandingan ketinggian media pasir halus:pasir kasar:kerikil sebesar 50:5:5 cm. Media yang digunakan merupakan batuan andesit yang mudah ditemukan di daerah Sumatra Barat. Debit air yang dialirkan pada biosand filter adalah 0,6 L/menit. Waktu penumbuhan biofilm selama 21 hari dan pengoperasian reaktor selama 14 hari. Setelah dilakukan analisis, reaktor biosand filter mampu menyisihkan parameter BOD dan COD. Efisiensi penyisihan konsentrasi BOD oleh reaktor biosand filter sebesar 75\%-87\%, dan efisiensi penyisihan konsentrasi COD oleh reaktor biosand sebesar 65\%-70\%. Maka dapat disimpulkan bahwa reaktor biosand filter cukup efektif dalam menyisihkan parameter BOD dan COD.
\end{abstract}

Kata-kata Kunci : Air Tanah Dangkal, Andesit Biosand Filter, BOD, dan COD,

\begin{abstract}
Shallow ground water is an options are commonly used by the people as a clean water. High levels of Biochemical Oxygen Demand (BOD) and Chemical Oxygen demand (COD) is in shallow ground water indicates the contamination of water. Therefore, we need an appropriate water treatment technology which is relatively inexpensive and efficient for society like biosand filter. The study aims to analyze the performance of biosand filters in reducing BOD and COD in shallow groundwater samples from wells. Biosand filter is designed with reactor dimensions of $30 \times 30 \times 90 \mathrm{~cm}$ with a height ratio of fine sand: coarse sand : gravel at 50:5:5 cm. The medium used is andesite that are easily found in the area of West Sumatra. Water discharged in biosand filter is $0.6 \mathrm{~L} / \mathrm{min}$. Biofilm growth in 21 days of and operation of the reactor was carried out for 14 days. Results showed that biosand filters reactor are capable of removing BOD and COD. $B O D$ removal efficiency by biosand filter was $75 \%-87 \%$, and the of COD removal efficiency was $65 \%-70 \%$. It can be concluded that the biosand filter reactor are quite effective in reducing the level of BOD and COD from shallow groundwater.
\end{abstract}

Key words : Shallow Groundwater, Andesite, Biosand Filters, BOD, and COD , 


\section{PENDAHULUAN}

Masyarakat Kota Padang menggunakan air tanah yaitu karena tingkat pelayanan PDAM hanya mencapai 75\% (PDAM, 2013). Selain itu, berdasarkan hasil penelitian yang dilakukan oleh Dinas Kesehatan Sumatera Barat, sekitar 70\% kuantitas air baku yang digunakan sebagai air minum di Sumatera Barat sudah memenuhi standar, namun 30\% sisanya masih belum layak dan dikhawatirkan menyebabkan gangguan kesehatan bagi masyarakat. Oleh karena itu, Dinas Kesehatan Sumatera Barat terus melakukan upaya menekan angka penyakit berbasis lingkungan melalui sosialisasi kepada masyarakat, dengan jalan menguji kualitas air minum. Air tanah dangkal umumnya berada pada kedalaman kurang dari $40 \mathrm{~m}$ dari permukaan tanah. Air tanah dangkal sangat mudah dipengaruhi oleh kondisi lingkungan setempat, karena antara air tanah dangkal dan air yang ada di permukaan tanah tidak dipisahkan oleh lapisan batuan yang kedap. Jika terjadi hujan, air yang meresap ke dalam tanah akan langsung menambah air tanah ini.

Melihat permasalahan yang timbul, maka salah satu upaya yang dilakukan untuk mendapatkan air bersih adalah dengan memanfaatkan teknologi tepat guna dalam skala kawasan rumah tangga. Kebutuhan teknologi tersebut juga ditinjau dari aspek biaya, kemudahan material, dan efektif dalam penyisihan kontaminan salah satunya kandungan Biochemical Oxygen Demand (BOD) dan Chemical Oxygen Demand (COD). BOD adalah jumlah oksigen yang dibutuhkan oleh mikroorganisme dalam lingkungan air untuk memecah (mendegradasi) bahan buangan organik yang ada dalam air pada kondisi aerob (Sawyer, 2003). Sedangkan COD menggambarkan jumlah total oksigen yang dibutuhkan untuk mengoksidasi bahan organik secara kimiawi, baik yang dapat didegradasi secara biologis maupun yang sukar didegradasi secara biologis menjadi $\mathrm{CO}_{2}$ dan $\mathrm{H}_{2} \mathrm{O}$. COD merupakan ukuran bagi pencemaran air oleh zat-zat organik yang secara alamiah dapat dioksidasi melalui proses mikrobiologis dan mengakibatkan berkurangnya oksigen terlarut di dalam air. Bakumutu BOD dan COD pada sumber air diatur dalam PP No
82 Tahun 2001 sebesar $2 \mathrm{mg} / \mathrm{L}$ untuk BOD dan COD sebesar $10 \mathrm{mg} / \mathrm{L}$.

Biosand filter merupakan filter yang khusus didesain untuk skala rumah tangga. Pada biosand filter terdapat penumbuhan biofilm yang dilakukan secara batch di permukaan media paling atas dimana lapisan biofilm ini mampu mendegradasi senyawa organik, rasa, bau dan warna (CAWST,2012). Dari penelitian yang pernah dilakukan, biosand filter ditinjau dari penyisihan, diantaranya mampu menyisihkan E.Coli $97 \%$, protozoa $>90 \%$, organik dan anorganik $50-90 \%$, besi 90-95\%, dan arsen 85-90\% (Lea, 2008). Selain itu, biosand filter mampu menyisihkan kandungan COD sebesar 67,54\% (Utami, 2013).

Sebagai media yang digunakan daam reaktor biosand filter dapat digunakan batuan andesit yang mudah di temukan di Sumatera Barat. Andesit memiliki luas permukaan silika yang besar $300-800 \mathrm{~m}^{2} / \mathrm{g}$, akibat dari banyaknya pori yang dimilikinya. Sifat yang paling penting dari silika adalah sebagai adsorben yang dapat diregenerasi. Silika memiliki kemampuan menyerap yang sangat besar terhadap molekul-molekul air. Dengan bertambahnya luas permukaan silika, porositas silika juga akan bertambah (Mahmoud, 2000).

Untuk menganalisis kemampuan kinerja alat biosand filter tersebut, maka perlu dilakukan penelitian untuk uji kinerja biosand filter dalam menurunkan kadar BOD dan COD pada air sumur yang dijadikan sumber air bagi penduduk.

\section{METODOLOGI PENELITIAN}

Untuk tata cara pengambilan sampel air tanah mengacu pada SNI 06-2412-1991. Alat yang digunakan untuk sampling air tanah berupa vertical water sampler, dan wadah bertutup ukuran $25 \mathrm{~L}$ dan $35 \mathrm{~L}$ untuk penampung sampel. Sampel air tanah dangkal diambil pada daerah yang belum terakses oleh PDAM dan memiliki kadar BOD dan COD yang tinggi di suatu daerah di Kota Padang Sumatera Barat.

Biosand filter terbuat dari bahan fiber glass dengan dimensi panjang $30 \mathrm{~cm}$, lebar $30 \mathrm{~cm}$ dan tinggi $90 \mathrm{~cm}$. Biosand filter berisikan media yang terdiri dari batuan andesit yang didapatkan dari pabrik aspal yang terdapat di 
daerah Kasang Kota Padang Sumatera Barat. Ketinggian media yang digunakan antara pasir halus:pasir kasar:kerikil yaitu 50:5:5 $\mathrm{cm}$ dan tinggi air saat pause period $5 \mathrm{~cm}$ di atas permukaan pasir halus. Pasir yang digunakan adalah pasir pecahan batu yang mudah didapat oleh masyarakat, dalam penelitian ini digunakan pasir andesit yang memiliki diameter $<1 \mathrm{~mm}$ untuk pasir halus, diameter $1 \mathrm{~mm}-6 \mathrm{~mm}$ untuk pasir kasar dan diameter $6 \mathrm{~mm}-15 \mathrm{~mm}$ untuk lapisan underdrain. Ukuran pasir diperoleh dengan melakukan pengayakan. Pasir dan kerikil dicuci dengan air bersih dan diaduk dalam

bak. Pasir dan kerikil terus dicuci hingga air bekas cucian tampak jernih kemudian dikeringkan dengan cara dijemur di bawah sinar matahari. Setelah kering pasir dan kerikil dimasukkan ke dalam reaktor. Proses memasukkan pasir dilakukan secara bertahap. Pertama dimasukkan kerikil pada lapisan dasar reaktor, pasir kasar lalu pasir halus pada lapisan atas. Setelah pasir dan kerikil masuk ke dalam reaktor, maka dilakukan pemadatan secara perlahan untuk memadatkan pasir dan mudah dilakukan pengukuran ketinggian media yang diharapkan. Skema reaktor biosand filter dapat dilihat pada Gambar 1

Penumbuhan biofilm dilakukan dengan cara menuang sampel ke dalam biosand filter, air hasil filtrasi awal dibiarkan keluar hingga tersisa air setinggi $\pm 5 \mathrm{~cm}$ diatas media pasir halus lalu dibiarkan selama $\pm 14-21$ hari untuk mendapatkan kualitas effluent yang maksimal. Biofilm akan tumbuh di atas lapisan pasir halus. Agar lapisan biofilm cepat terbentuk, dilakukan penambahan gula sebanyak $0,2 \mathrm{gr} / 100 \mathrm{~mL}$ air. Penambahan gula ini dilakukan 2-3 hari sekali.

Setelah biofilm tumbuh, sampel dialirkan ke dalam reaktor menggunakan kran dengan debit $0,6 \mathrm{~L} /$ menit. Ketinggian sampel dalam reaktor dijaga tetap $\pm 5 \mathrm{~cm}$ di atas plat diffuser. Hal ini dilakukan dengan cara memberikan lubang pada dinding reaktor untuk overflow Saat reaktor beroperasi, dilakukan pengambilan sampel pada outlet untuk diukur kandungan. Analisis parameter BOD dan COD pada sampel ini dilakukan sebelum sampel tersebut diolah dan setelah diolah atau disisihkan oleh biosand filter. Metode analisis BOD yaitu dengan menggunakan metode winkler, dimana nilai hasil parameter BOD dapat diketahui setelah lima hari dalam bentuk $\mathrm{BOD}_{5,}$. Metode pengukuran COD menggunakan metode titrasi dengan oksidator kalium dikromat. Pada pengujian COD digunakan alat COD reaktor (merk : HACH, type DRB 200) untuk memanaskan campuran larutan digesi, $\mathrm{Ag}_{2} \mathrm{SO}_{4} \mathrm{H}_{2} \mathrm{SO}_{4}$ dan sampel pada suhu $120^{\circ} \mathrm{C}$ selama 2 jam.

\section{HASIL DAN PEMBAHASAN}

\section{Penurunan Kadar BOD dari air tanah}

Hasil analisis menunjukkan bahwa nilai effluent mulai stabil pada hari ke-8 sampai hari ke-14. Dilihat dari dari grafik pada Gambar 2, dimana konsentrasi influent masih jauh di atas baku mutu PP No 82 Tahun 2001. Hasil penyisihan dari reaktor biosand filter ini belum dapat menyisihkan BOD hingga mencapai standar yang ditetapkan

Mekanisme yang terjadi di dalam reaktor biosand filter yaitu mechanical trapping, adsorpsi, dan predation (CAWST, 2009). Saat sampel masuk, partikel diskrit terendapkan di permukaan pasir paling atas. Antara Partikel dan mikroorganisme yang masuk kemudian melekat satu sama lain dan membentuk flok. Setelah itu, flok tersebut tersebut tersuspensi. Flok yang tersuspensi akan mengalir melalui celah media dan jika ukuran flok lebih besar dibandingkan dengan rongga media, maka flok tersebut akan terjebak di dalam rongga media sehingga partikel yang mampu melewati rongga adalah partikel yang ukuran lebih kecil dari rongga media andesit.

Saat mekanisme penyisihan, terjadi tarik menarik antara partikel dengan media andesit, antara mikoorganisme dengan media andesit, dan antara mikroorganisme pada lapisan biofilm dengan mikroorganisme yang akan disisihkan. Kemampuan media menarik partikel dan mikroorganisme disebabkan adanya gaya van der walls. Gaya inilah yang mendukung proses adsorpsi media andesit (CAWST, 2009). 


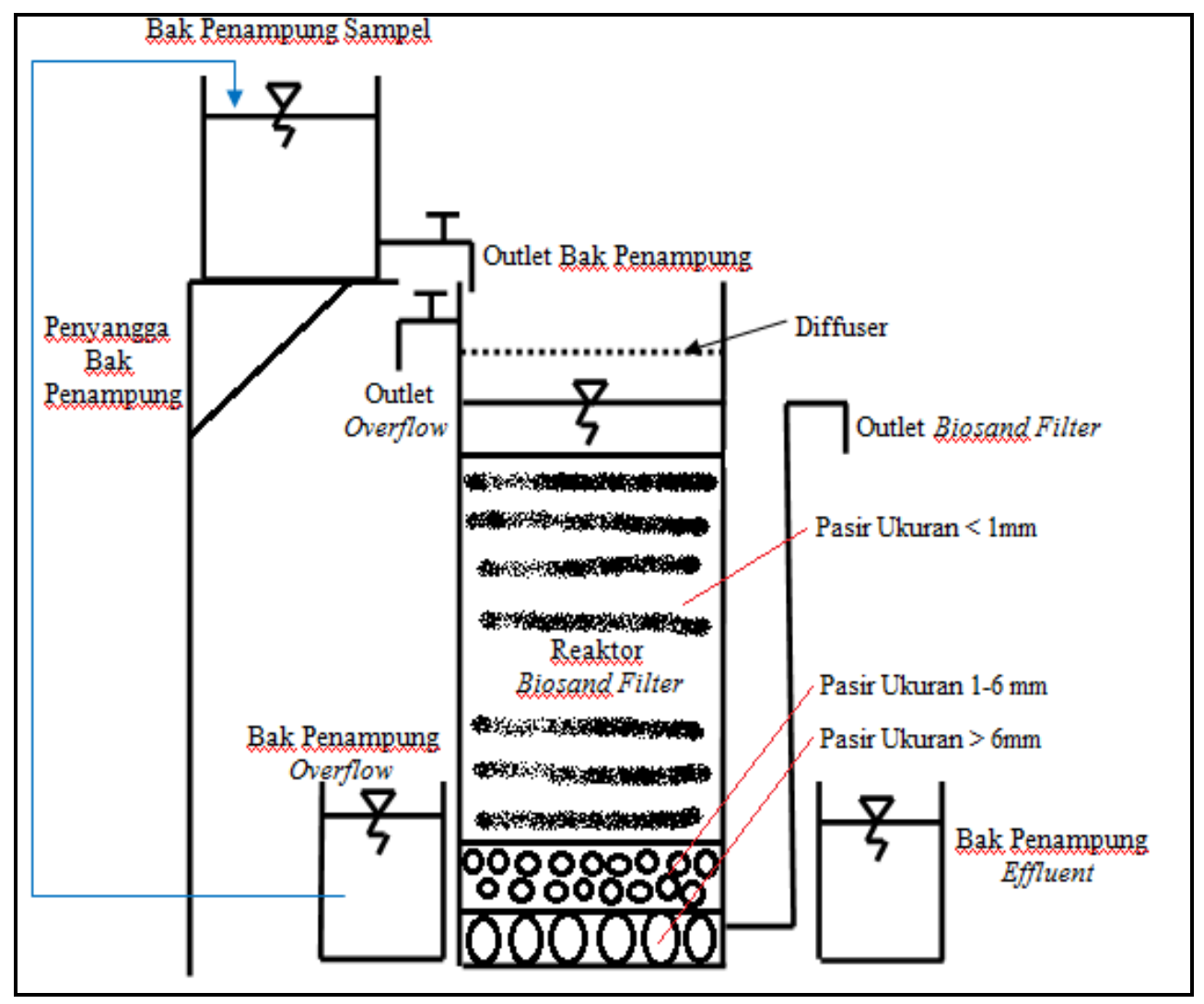

Gambar 1. Skema Biosand Filter

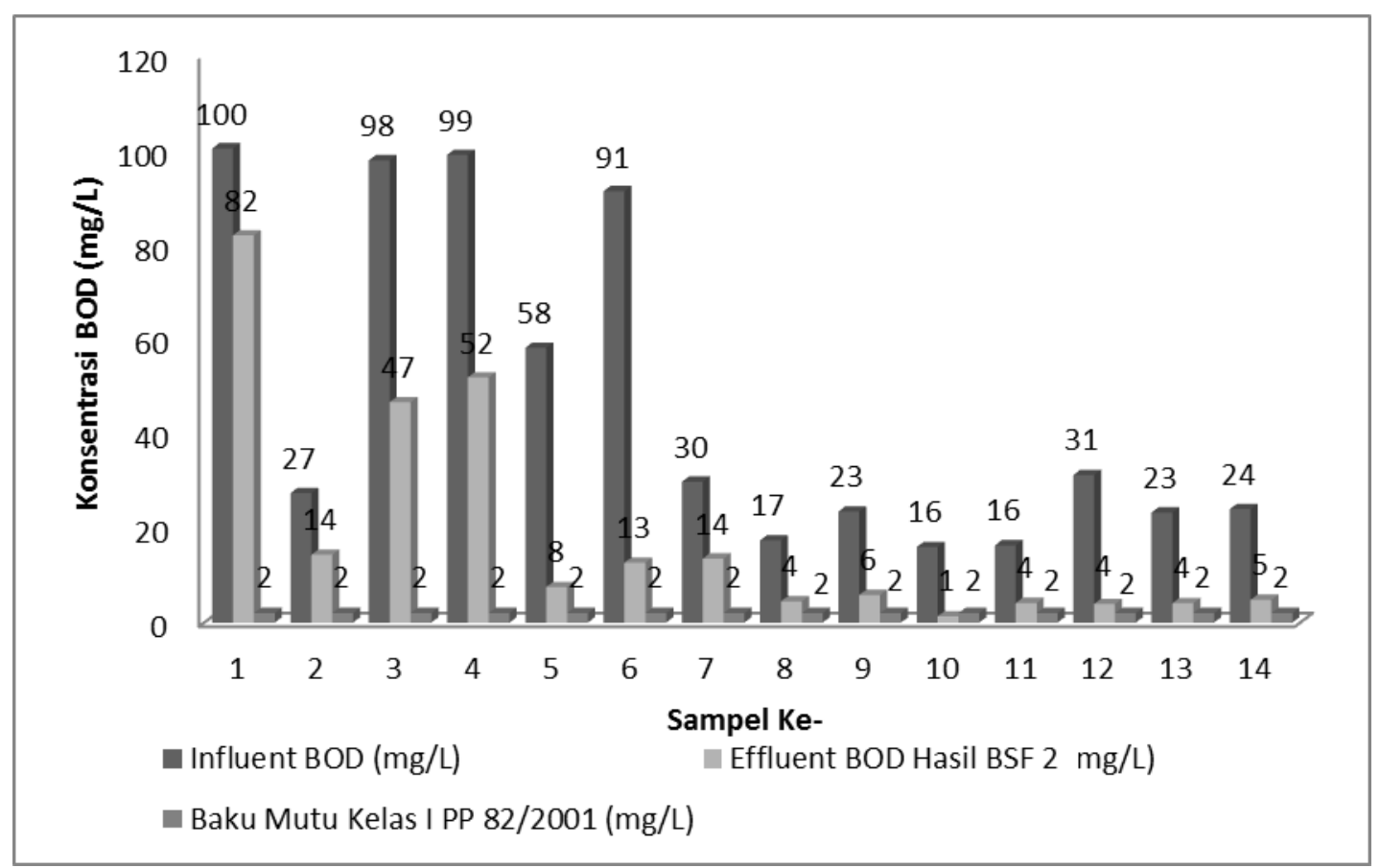

Gambar 2. Konsentrasi Influent dan Effluent Reaktor Biosand Filter 2 
Penurunan nilai BOD terjadi karena mikroorganisme yang terdapat di lapisan biofilm mampu mendegradasi bahan organik secara biologi dan kimia menjadi bahan yang lebih sederhana (Avlenda, 2009). Pada proses predation, mikroorgansime pada lapisan biofilm memangsa mikroorganisme yang lebih kecil dan lebih lemah. Dalam hal ini, mikroorganisme yang bertindak sebagai pemangsa akan mengambil nutrisi dan karbon dari mikroorganisme lain. Nutrisi dan karbon tersebut akan dijadikan sebagai makanan dan pasokan energi untuk keberlangsungan hidup (CAWST, 2009).

Setelah dilakukan analisis terhadap hasil penyisihan BOD, maka didapatkan nilai efisiensi penyisihan BOD oleh biosand filter pada Gambar 3. Pada saat pertama kali beroperasi, efsiensi penyisihan BOD sebesar $18 \%$ namun pada pengujian sampel ke-2 terjadi kenaikan penyisihan sebesar $48 \%$. Berdasarkan grafik tersebut, penyisihan BOD terjadi secara fluktuatif mulai saat pengujian sampel ke-1 hingga sampel ke-10. Penyisihan berfluktuasi dapat terjadi dikarenakan mikroorganisme yang berada di lapisan biofilm belum mampu beradaptasi dengan kondisi lingkungan dan karakteristik dari sampel yang masuk. Kondisi lingkungan dan karakteristik sampel selalu berbeda-beda dikarenakan sampel diambil selama 14 hari.

Meskipun sampel yang dimasukkan selalu berbeda-beda, namun efisiensi penyisihan dapat stabil. Kestabilan penyisihan dimulai pada sampel ke-11 dengan nilai sebesar $75 \%$. Peningkatan dan kestabilan pada efisiensi penyisihan terjadi dikarenakan mikroorganisme sudah mulai mampu beradaptasi dengan kondisi yang ada di dalam reaktor dan kondisi sampel yang masuk. Kemampuan mikroorganisme dalam beradaptasi menandakan bahwa mikroorganisme berada dalam fase pertumbuhan dan pada saat stabil, mikroorganisme berada dalam fase stasioner/statis. Kemampuan mikroorganisme beradaptasi dan menyisihkan BOD juga didukung oleh jumlah substrat, nutrisi, dan oksigen yang masuk sehingga cukup untuk makanan dan energi yang dibutuhkan oleh mikroorganisme (Stoodley, 2002). Selain itu, Kemampuan adsorpsi antara media dan substansi yang semakin kuat (CAWST, 2012). Dilihat dari grafik efisiensi penyisihan, maka dapat disimpulkan bahwa kemampuan biosand filter 2 dalam menyisihkan BOD sebesar 75-87\%.

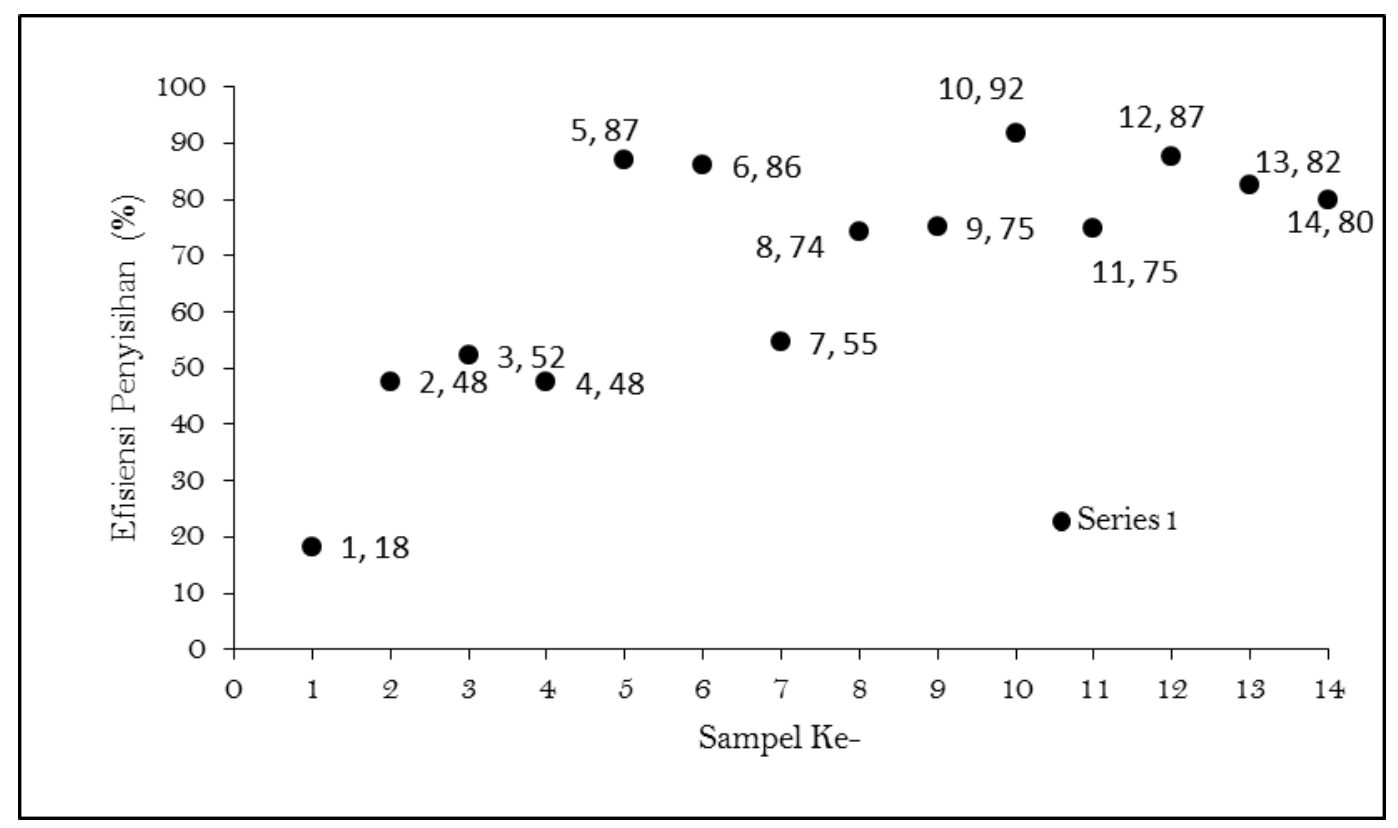

Gambar 3. Efisiensi Penyisihan Oleh Reaktor Biosand Filter 


\section{Penurunan Kadar COD dari air tanah}

Penurunan kadar COD pada air tanah dangkal menggunakan biosand filter dapat dilihat pada Gambar 4. Pada proses penyisihan COD juga menghasilkan nilai Effluent yang bersifat fluktuatif diakibatkan karena influent yang masuk juga bersifat sangat bervariasi. Secara garis besar asil penyisihan dari reaktor biosand filter ini belum dapat menyisihkan COD hingga mencapai standar baku mutu kelas I PP No 82 Tahun 2001 sebesar $10 \mathrm{mg} / \mathrm{L}$.

Pada saat pertama kali beroperasi, nilai efsiensi penyisihan sebesar 13\% namun pada sampel ke-2 turun naik menjadi $20 \%$, hingga tingkat penyisihan mulai stabil pada sampel ke-10 dengan nilai $70 \%$. Nilai efisiensi penyisihan dapat dilihat pada Gambar 5. Pada sampel ke-1 hingga ke-10, terjadi hasil yang berfluktuasi disebabkan mikroorganisme yang berada pada lapisan biofilm belum mampu beradaptasi dengan kandungan air yang masuk dan media yang digunakan. Fluktuasi konsentrasi influent, effluent, dan efisiensi penyisihan juga terjadi pada penelitian sebelumnya dimana efisiensi penyisihan COD dengan pengujian sapel dilakukan tiap dua hari sekali selama delapan hari yaitu $60 \%, 82 \%, 73 \%$, dan $56 \%$ (Utami, 2013).

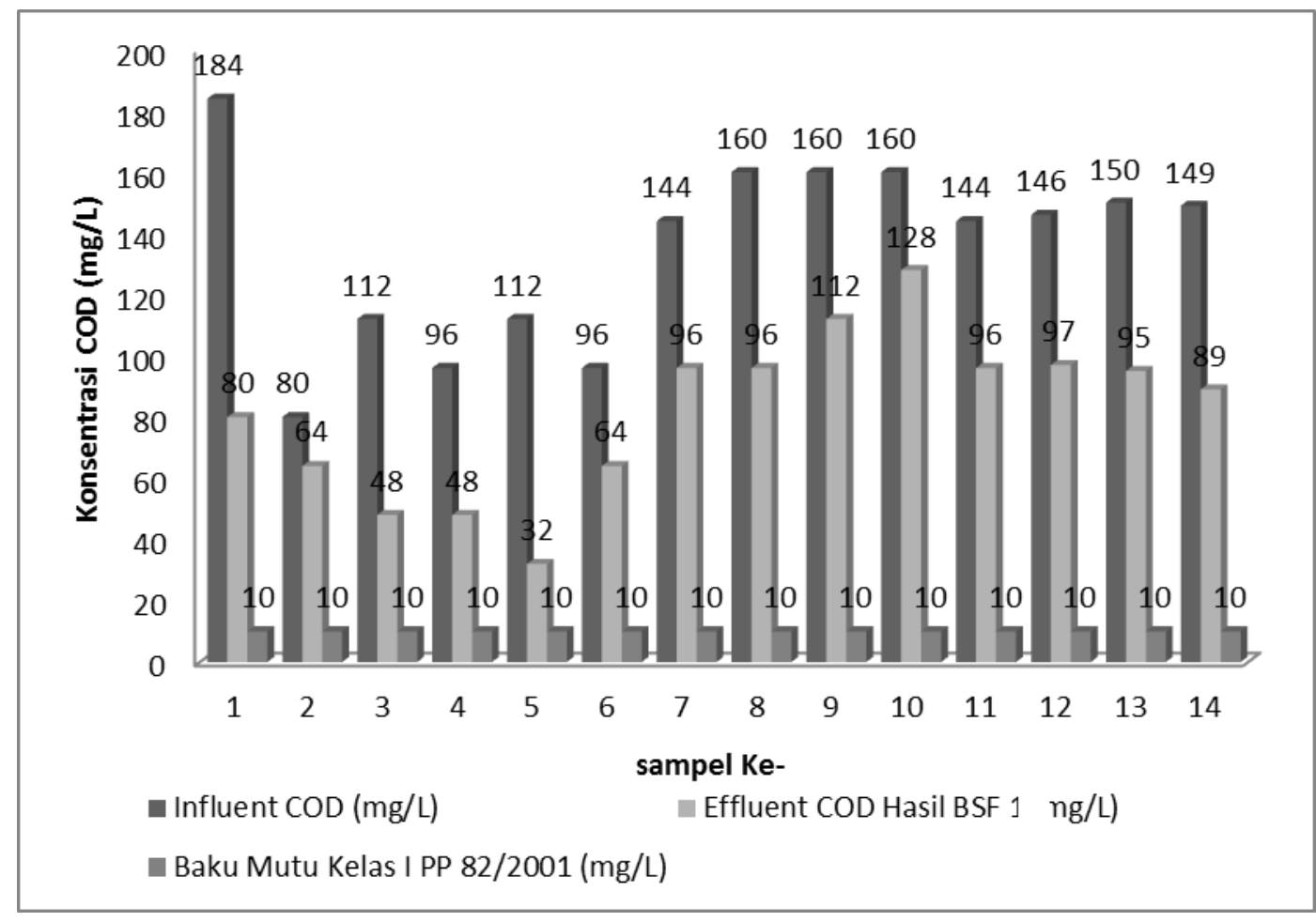

Gambar 4. Konsentrasi Influent dan Effluent Reaktor Biosand Filter

Nilai efisiensi penyisihan tertinggi yaitu pada sampel ke-5 dengan nilai sebesar $71 \%$ dan efisiensi terendah pada sampel pertama yaitu sebesar $20 \%$. Ditinjau dari besarnya selisih antara efisiensi penyisihan COD tersebut, pada efisiensi tertinggi, mikroorganisme mendapatkan nutrisi dan energi yang cukup. Begitu juga dengan meningkatnya kemampuan dalam mengadsorpsi bahan organik dan partikel yang masuk. Penurunan efisiensi terjadi kemingkinan dikarenakan kurangnya substrat, karbon, oksigen pasokan energi tidak cukup bagi mikroorganisme dalam mendegradasi kandungan COD yang masuk pada hari itu. Selain itu, efisiensi yang rendah juga diakibatkan karena adanya endapan yang tertinggal pada penysihan sebelumnya. Endapan tersebut tidak dapat ditahan/disaring oleh media sehingga ikut terbawa pada proses penyisihan. Endapan yang terbawa menyebabkan konsentrasi 
menjadi tinggi dan efisiensi menjadi rendah. Setelah dalam keadaan stabil, dimana mikroorganisme pada biofilm mulai beradaptasi dengan kondisi sampel maka didapatkan nilai efisiensi penyisihan COD sebesar $65-70 \%$.

Nilai rata-rata efisiensi penyisihan COD pada reaktor biosand filter sebesar $66,4 \%$, dengan ketinggian media pasir halus:pasir kasar:kerikil (50:5:5) $\mathrm{cm}$. Berbeda dengan penelitian telah dilakukan sebelumnya, dengan perbandingan ketinggian media yang digunakan antara pasir halus:pasir kasar:kerikil $(50: 10: 10) \mathrm{cm}$, penyisihan ratarata selama 8 hari penelitian sebesar 54,96\% sedangkan pada ketinggian media $(30: 20: 15) \mathrm{cm}$ efisiensi penyisihan rata-rata sebesar 67,54\% (Utami, 2013).

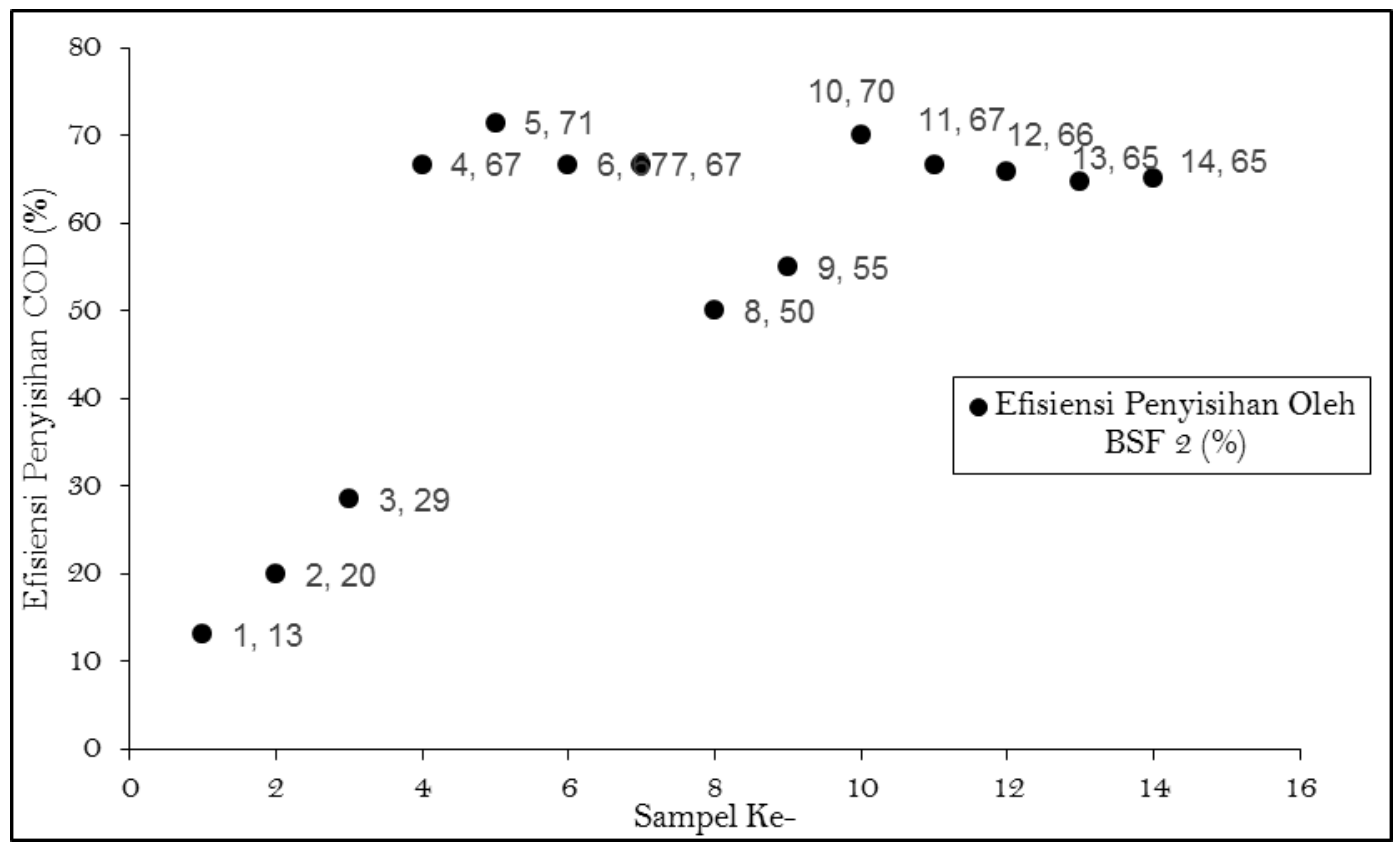

Gambar 5. Efisiensi Penyisihan Oleh Reaktor Biosand Filter 2

\section{SIMPULAN}

Dari penelitian yang dilakukan didapatkan simpulan bahwa biosand filter dengan batuan dasar andesit mampu menurunkan kadar BOD dan COD pada air tanah dangkal. Penyisihan BOD mulai stabil setelah beberapa hari setelah reaktor bisand fiter dijalankan, yakni mulai pada hari ke-10 dari 14 hari pengoperasian reaktor, sedangkan kadar COD ditemukan sangat fluktuatif selama 14 hari tersebut. Penurunan kadar BOD dan COD yang didapatan masih di atas bakumutu yang telah ditetapkan PP No. 82 Tahun 2001.

Penelitian selanjutnya dapat dilakukan dengan mengujicobakan jenis batuan atau pasir lainnya sebagai media biosand filter untuk menurunkan kadar BOD dan COD pada sumber air, serta memvariasikan ketinggian media agar didapatkan penurunan kadar BOD dan COD yang optimal.

\section{DAFTAR PUSTAKA}

Avlenda, E. 2009. Penggunaan tanaman Kangkung dan Genjer Dalam Pengolahan Limbah Cair Kelapa Sawit. Bandung: Tesis Pasca Sarjana Biologi Institut Teknologi Bandung

Badan Geologi Dinas Pertambangan dan Energi Provinsi Sumatera Barat Tahun 2011

Center for Affordable Water and Sanitation Technology (CAWST). 2009. Biosand Filter Manual Design, Construction, Installation, Operation And Maintenance. http://www.cawst.org. diakses tanggal 15 September 2013

Center for Affordable Water and Sanitation Technology (CAWST). 2012. Biosand 
Filter Literature Summary September 2012 Edition. Center for Affordable Water and Sanitation Technology. Available at: http://www.cawst.org.Diakses tanggal 15 September 2013

Ati, E.K dan Djoko M, Bowo. 2012. Studi Kinerja biosand Filter Untuk Pengolahan Air Minum ditinjau Terhadap Parameter Warna Dan E. Coli. Tugas Akhir. Jurusan Teknik Lingkungan FTSP-ITS, Surabaya

PDAM. 2013. Data Pelayanan PDAM Padang

http://bapedalda.sumbarprov.go.id/ko ndisilh-143-kualitas-air-sumur.html. Diakses tanggal 10 September 2013

Lea, M. 2008. Biological Sand Filters: LowCost Bioremediation Technique For Production OfClean Drinking Water

Mahmoud, M.E., Osman, M.M., Amer, M.E., 2000, Selective Preconcentration and Solid Phase Extraction of Mercury(II) from Natural Water by Silica Gel- Loaded Dithizone Phases, Anal.
Sawyer, Clair. N., Mc Carty, Perry L and Gene F. Parkin. 2003. Chemistry for Environmental Engineering Fifth Edition. USA : McGraw Hill Book., Co.

Sari, N.M. 2010. Studi Kinerja Biosand Filter Untuk Pengolahan Air Minum Skala Rumah Tangga Ditinjau Terhadap Parameter Kekeruhan Dan Besi. Tugas Akhir. Jurusan Teknik Lingkungan FTSP-ITS, Surabaya

SNI 06-2412-1991 Tentang Metode Pengambilan Contoh Kualitas Air.

Stoodley P, Sauer K, Davies DG, Costerton JW. 2002. Biofilms as complex differentiated communities. Center for Biofilm Engineering, Montana State University, Bozeman : USA

Utami R.A. 2013. Pengolahan Limbah Cair Laundry dengan Menggunakan Biosand Filter dan Activated Carbon. Tugas Akhir. Teknik Lingkungan Jurusan Teknik Sipil Fakultas Teknik Universitas Tanjungpura 